ARTICLE

\title{
Multi-Dimensional Trust Between Partners for International Online Collaborative Learning in the Third Space
}

\author{
*Brett McCollum ${ }^{a}$, Layne Morsch ${ }^{b}$, Chantz Pinder ${ }^{b}$, Isaiah Ripleyc, Darlene Skagen ${ }^{\text {, }}$, and \\ Michael Wentzelc. \\ ${ }^{a}$ Department of Chemistry and Physics, Mount Royal University, Canada \\ ${ }^{b}$ Department of Chemistry, University of Illinois - Springfield , USA \\ 'Department of Chemistry, Augsburg University, USA
}

Contact: $\underline{\text { bmccollum@mtroyal.ca }}$

\section{ABSTRACT}

The International Network for Chemistry Language Development is a community of faculty and students that employ video conferencing technologies in collaborative learning experiences. Learners partner with an international peer at another university to complete online collaborative assignments (OCAs). OCAs focus on shared learning and professional experience rather than assessment of knowledge to practice chemistry communication in the oral, written, and symbolic domains. We present OCAs as an example of the Third Space, where control over interactions and learning is negotiated between unfamiliar remote students, empowering students as emerging experts. This digital Third Space results in the formation of trust (a) between student partners to prepare for-and contribute during - the OCAs, and (b) between students and faculty as partners in teaching and learning. Additionally, we report how revisions to the OCA design are achieved with current students as consultants and partners, and former students as co-researchers and co-designers.

\section{KEYWORDS}

collaboration, chemistry, online learning, students as partners, trust, third space

Efforts to promote student participation in educational decision-making have recently garnered increased attention (Cook-Sather, Bovill, \& Felten, 2014; Bovill \& Felten, 2016; Cliffe et al., 2017). The contribution of students as consultants on the redesign of learning activities can be considered an introductory level of engagement, or may scale up to a Students-asPartners (SaP) level of engagement when students and faculty have joint ownership and decision-making authority (Healey, Flint, \& Harrington, 2014).

Empowering students to be co-learners does not come without challenges from the faculty perspective (Bovill, Cook-Sather, Felten, Millard, \& Moore-Cherry, 2016; Sundberg, 
Josephson, Reeves, \& Nordquist, 2017; Murphy, Nixon, Brooman, \& Fearon, 2017) or student perspective (Bovill et al., 2016; Cook-Sather et al., 2014). Faculty and students may have different motivations for partnership (Acai et al., 2017). Additionally, students - like facultyare individuals, and as a collective may not agree on a strategy to improve the educational experience (McCollum, Fleming, Plotnikoff, \& Skagen, 2017; McCollum, Morsch, Skagen, \& Shokoples, in press).

Given the various dynamics at play in SaP structures, the Third Space in higher education (Bhabha, 1994) provides valuable opportunities for partnerships as well as an interesting lens for examining these partnerships. Soja and Chouinard (1999) conceptualized Third Space as the lived space that coexists with the material and the representational. Gutiérrez (2008) describes the Third Space as a social environment of development "in which students begin to reconceive who they are and what they might be able to accomplish academically and beyond" (p. 148), providing a conceptualization of Third Spaces as physical, such as field work, or virtual, such as a shared web space. Third Spaces empower students to explore the boundaries of expertise outside of conventional hierarchies (Wegner, 2011), and can include digital spaces, constructed through digital technologies such as video conferencing, text messaging, and social media (Potter \& McDougall, 2017). Drawing upon the conceptualizations of Gutiérrez and Potter and McDougall, a digital Third Space can refer to a space between the classroom (i.e., first space) and workplace (i.e., second space), in which the boundaries of learner and professional are blurred through online communication.

We present a case study of a semester-long international collaborative learning experience in a digital Third Space that actively engages students in multiple ways. First, current students contribute as consultants with faculty on the design of the experience. Second, current students partner with faculty and an international peer as co-learners that choose which professional skills they will prioritize during the experience, and determine how they will conduct the learning process based on their mutual needs. Third, former students partner with faculty as co-researchers, investigating the learning experience and impact. Fourth, former students partner with faculty as co-designers of the revised assignments to improve the experience and accentuate the impact. This case study will demonstrate the importance of trust in the Third Space. Specifically, it demonstrates that learners engage in a Third Space when they: (a) understand that deviation from traditional hierarchies is encouraged, (b) have confidence that their partner has the necessary ability and willingness to likewise prepare and contribute to meetings, and (c) trust that the assessment practice for a Third Space permits or even encourages failure as part of learning. We will reveal that students are initially hesitant to accept the role of co-learner but quickly transform through partnerships with faculty and with international peers as they embrace agency over their collaborative learning. We will examine how trust between partners in a Third Space is a foundation for the emergence of student ownership over learning. Ethical approval for this research was granted at each participating university.

\section{CASE DESCRIPTION: ONLINE COLLABORATIVE LEARNING}

Undergraduate organic chemistry students in Canada ( $\mathrm{n}_{\mathrm{MRU}} 2016=57 ; \mathrm{n}_{\mathrm{MRU}}, 2017=70$ ) were connected with learners at two universities in the United States $\left(n_{U I S, 2016}=65 ; n_{U I S, 2017}=37\right.$; 
$\mathrm{n}_{\mathrm{AU}, 2017}=38$ ) for a series of online collaborative learning experiences in a second-year course. Students were grouped into teams of two or three so that at least one American student was paired with a Canadian student. Demographics on the student populations has been reported previously (Skagen, McCollum, Morsch, \& Shokoples, 2018).

These online collaborative learning interactions are a Third Space where learners participate in realistic professional experiences. Students engage with a stranger in their field and conduct professional conversations using the internationally accepted terminology of the field (International Union of Pure and Applied Chemistry [IUPAC], n.d.). The impact of the online collaborations includes improved chemistry communication confidence and proficiency (Skagen et al., 2018; McCollum et al., in press), improved reading habits (McCollum \& Morsch, 2019), emergence of professional identity (Skagen et al., 2018), and exposure to global aspects of scientific professions (Skagen, McCollum, Morsch, \& Wentzel, 2019). Chemistry students are accustomed to a traditional lecture-based learning environment. There is period of adjustment as learners explore their roles in a Third Space, collaboratively negotiating shared expectations for the learning experience. For example, one student stated:

Beginning the semester, I was a little uneasy about the online collaborative process. ... As my partner and I began to trust one another, it became much more comfortable for me to reach out to my partner... This experience also serves another function of providing me with essential professional skills to be used in the future.

The faculty role in this Third Space changed over time, with three significant contributions in the initial implementation. First, faculty collaborated to align their course curriculum and semester schedules (Skagen et al., 2018) to ensure that students could engage with each other as equal partners and that the courses still met departmental expectations. Second, faculty collaborated on the initial assignment design. Third, faculty connected international student pairs, and connected students with a new international peer if their partner dropped the course. Although faculty provided solutions for the course content questions, they did not assess student submissions for accuracy. Instead, students were encouraged to engage in a meaningful shared learning experience as a professional-in-training and to document the interactions. Faculty then provided feedback on the documentation as evidence of meaningful professional interactions.

These online collaborative assignments (OCAs) involved weekly web-based video chat with an international partner. The assignments were designed with the vision of stimulating team-based learning in a digital space that could connect learners that did not share a common classroom experience. In this way, students drew upon their developing content knowledge without relying on shared memories of what the instructor had done or said in the classroom. Learners were invited and challenged to explore connections between their expertise in chemistry, communications technology, and inter-personal professional interactions. This created a learning environment in which students were empowered to make decisions about how and when they would connect with their partner; how they would conduct their interactions; how they share the roles of learner, teacher, and expert with their partner; and which professional skills they would prioritize for development during the experience. For 
example, some students reported learning how to conduct a meeting over video chat and how to facilitate the meeting effectively and efficiently. Others described learning how to move between roles of teacher and learner, sharing their understanding of course material and then pausing to patiently listen and constructively critique an explanation from their partner. Although there were similarities in how different partnerships functioned, the journey that each partnership went through to mutually negotiate their interactions in this digital Third Space was distinct. Faculty did not give direction on how partnerships were intended to function. They only identified a general means of communication (i.e., online video chat), provided shared tasks in accordance with the principles of collaborative learning (Barkley, Major, \& Cross, 2014), and chose an assessment practice that would encourage learners to explore the possibilities inherent in collaborative learning as opposed to the outcome (Skagen et al., 2018).

If the design of the experience had stopped here, faculty would have maintained significant authority over the experience. An authentic faculty-student partnership was organized to co-investigate, co-research, and co-design future implementations of the experience. Since the first implementation, students have engaged in redesign of the experience as consultants and partners and informed the redesign as co-researchers. Over time, the online collaborative learning experience has evolved into a Third Space where students and faculty collaborate as partners.

\section{Current students in the third space}

Although faculty support students through the experience by connecting them and providing a course-content purpose to initially stimulate their interactions, student partners take ownership over their shared experience. They co-create the social interactions and conversational boundaries, navigating and negotiating their relative expertise. In this way, student partners determine whose knowledge counts, and what personal experiences are valued in the professional interaction.

Through interviews and reflection assignments, students commonly discussed nervousness and the awkwardness of working with remote colleagues for the first time. Many of the students reported how these feelings pushed them to put more effort into preparation before the online meetings, which then made the collaborative work more successful. This instance of Social Comparison Concern (Festinger, 1954) appeared to yield a positive outcome of increased effort due to participants feeling accountable to their partners.

As the OCAs progressed, most student pairs realized that the different styles of their professors added value to their learning. The process of negotiating together towards a shared understanding was worth the initial discomfort. Additionally, the students reported dual roles as teachers and learners where they would alternate who would explain a specific concept and draw upon their classroom experiences. The partners had to determine together how to best develop shared understanding of the content. This consensus building allowed the students to take ownership of the learning process (Healey, Flint, \& Harrington, 2016).

The peer dynamic (rather than an instructor-student dynamic) made it easier for students to ask for help or clarification when needed. This allowed some students to think differently 
about who they are or what they might be able to achieve. Consider the following example reflection from a student:

The skill that they [my two partners] both have is actually a skill that I had to learn during the term because I was kind of hesitant to say when I thought something was wrong and why... So I actually had to learn how to do that and be confident sharing my ideas and giving and sharing criticism.

Student participants have contributed as consultants in redesigning the collaborative activity. One example comes from the first year of the project. Students at one campus were required to record and submit the video chat to their instructor. When the researchers reviewed the reflections and interviews, it became apparent that this seemingly small addition added significant stress to the activity and distracted students from the main focus of disciplinary communication. This video recording requirement was removed from all subsequent iterations of the activity.

Although students experienced barriers of being unfamiliar with each other and the process used in the OCAs, they soon took ownership of conducting the learning process and determining the learning outcomes achieved. Their feedback to the faculty throughout the process directly influenced future iterations of the OCAs.

\section{Former students in the Third Space}

Redesign of the OCAs over several years involved partnership with undergraduate research students. All of these co-researchers had previously completed the course, and many had also experienced the OCAs as learners and brought their experience to the research. Student research partners collaborated on experimental design, conducted all research interviews, collaborated over video chat with the international research team for data analysis, and co-authored manuscripts. Their perspective as near-peers of students in the course improved the data collection, as learners openly shared their opinions about the benefits and barriers of online collaborative learning (McCollum et al., in press).

Student research partners also worked with faculty to identify several problem areas of the OCAs and helped design the revisions. Perhaps the most significant redesign involved the student reflections. In the first iteration, reflections were completed collaboratively during the online meeting. Students and faculty agreed that submitted reflections were not meeting the learning goals. Student researchers who had experienced the OCAs as learners provided a deeper perspective on the challenges of reflecting on content knowledge acquisition with their partner during the online meeting. As a result, the faculty and student researchers redesigned the reflection components of the OCAs to be done individually after the online meetings. Furthermore, the focus of the reflections was changed to promote contemplation on skills development and experiences of online learning with a remote partner. This improved the quality of introspection and appreciation of the experience. Student partner engagement with the instructors at three universities directly influenced future iterations of the OCAs. The contributions of these student partners were integral to each of these improvements. 


\section{Emergence of trust}

Developing a pedagogy that employs a constant feedback loop through consultations and partnerships among current students, former students, and faculty allowed for the emergence of trust between parties. Student reflections after each OCA revealed that they recognized the value of this digital Third Space and provided on-going input on the redesign of the assignments. Furthermore, a "Letter from a Mentor" reflection is being used to guide current students on how they can interact with their OCA partner to co-create a shared learning environment.

Rather than being overly restrictive, the OCAs maintained flexibility in regards to how students employ the verbal, written, and symbolic modes of communication during their collaborative meetings. Thus, faculty trusted students to decide what technologies to use to organize and conduct their video conferencing meetings and for communication of content (i.e., oral, written, and symbolic communication), further putting an emphasis on students creating their own success in the assignments. For this reason, OCAs were not assessed for accuracy. Rather, the assignments were graded for evidence of collaborative effort and skill development.

Each year, a segment of students is initially unconvinced that organic chemistry should include assignments that stimulate professional skills rather than solely focusing on content knowledge. As a result of our SaP redesign efforts for the OCAs, faculty now invite students to engage in a classroom discussion and personalized contemplation about the purpose of OCAs. Students report becoming more aware of how these assignments increase their professional skills and that they have assumed ownership over which professional skills they prioritize.

Finally, one of the benefits of the OCAs was to have students develop trust in an unfamiliar professional colleague within the Third Space. In our experience, assignments requiring group work are often viewed as tedious and annoying to students, a perspective supported in the literature (Paterson, 2011). In contrast, by emphasizing the collaborative process and skill development rather than content accuracy alone, our students were able to work as co-learners and co-teachers and further experience the values of each role. Alternating between roles was an intentional design element of the OCAs. Though course content was the same across the three universities, faculty explanations in class and textbooks varied. The collaborative process that encouraged students to teach and learn from each other empowered them to share their varied descriptions of chemical phenomena.

Students reported needing to be more prepared for the experience than other collaborative projects. Specifically, they needed to know the content well enough to teach it to a remote peer who had not shared their classroom experience. Through this process, students learned professional skills such as preparation and promptness and how to trust an unfamiliar peer and earn trust in return, and they developed skills as a supportive peer collaborator. The emergence of trust between student partners is illustrated in the quote below from a student reflection:

Working with someone in a different country is not like working with study groups at the same school. You will benefit from a new point of view, a way of thinking coming from a different teaching style, and classes going at varying rates. My partner and I often 
collaborate outside of these video chats as well, which I highly suggest. Through these connections one may become a better teacher, and a better listener.

This student did not know their partner prior to the experience, and yet they forged a mutual trust wherein they willingly worked together beyond the OCAs, benefitting from each other's ways of thinking and embracing the roles of co-teachers and co-learners. They trusted their partner's ability to comprehend the material, to prepare for meetings, and to contribute to their own learning in a meaningful way.

\section{IMPACT AND FUTURE DIRECTIONS}

OCAs impacted current and former students as partners and collaborators with their professors. Trust within and between these groups was the foundation for the shared learning and occupation of the Third Space. Following this shared experience students realized benefits of trusting each other to facilitate their learning. Numerous students began using video conferencing to study with their partners or locally with fellow classmates. The shared trust was not a common starting point with students having preconceived notions of group work. However, after the OCAs and upon multiple reflections, most students valued the ability to learn on their own terms and in a space of their choosing, as shown in the student comment below:

Doing the exercises together can help you pinpoint common mistakes and misconceptions. I hate working in groups, and I had never studied with someone else before, but it still had benefits for me, and my partner and I learnt a lot from each other.

Our experience in designing and redesigning a series of collaborative learning assignments with student consultants and partners has revealed some of the challenges and benefits of this type of initiative. Beyond the course content, students report increases in ownership over their learning and trust in others to support their learning in a digital learning environment. Students describe new understanding of themselves as emerging professionals. It is these aspects of the learning-ownership over the learning, trust in others, and student input on design-that transform the learning environment into a Third Space. Additional research is needed that explores how "space" shapes trust and human interactions, and how hierarchies evolve or dissolve in digital spaces as expertise is redefined. We plan to explore additional avenues for providing students further control over the professional skills they develop through the Third Space of online collaborative learning.

\section{NOTE ON CONTRIBUTORS}

Brett McCollum is a Professor of Chemistry at Mount Royal University in Calgary, Canada, a 3M National Teaching Fellow, a Nexen Scholar of Teaching and Learning, and an MRU Distinguished Faculty Member. He is an Apple Distinguished Educator and an Associate Editor of LibreTexts OER. 
Layne Morsch is an Associate Professor of Chemistry at University of Illinois Springfield where his teaching has been recognized by the College Faculty Excellence in Teaching Award and two University Awards; the Burks Oakley II Distinguished Online Teaching Award and the Pearson Award for Outstanding Teaching. He is an Apple Distinguished Educator and Curator for LibreText OER.

Chantz Pinder is an undergraduate student at University of Illinois Springfield. His research activity was supported by a UIS College of Liberal Arts and Sciences Student-Faculty Creative Activities award.

Isaiah Ripley is an undergraduate student at Augsburg University in Minneapolis, MN. His research activity was supported by a Sundquist family grant.

Darlene Skagen is an undergraduate student at Mount Royal University in Calgary, Canada. Her research activity was supported by an Alberta STEP grant.

Michael Wentzel is an Associate Professor of Chemistry at Augsburg University in Minneapolis, $M N$ where his teaching has been recognized by the Augsburg student government as Professor of the Year 2017-18. He also is a 2018 Science Communication Fellow for Advancing Green Chemistry.

\section{REFERENCES}

Acai, A., Akesson, B., Allen, M., Chen, V., Mathany, C., McCollum, B., Spencer, J., \& Verwoord, R. E. (2017). Success in student-faculty/staff SoTL partnerships: Motivations, challenges, power, and definitions. The Canadian Journal for the Scholarship of Teaching and Learning, 8(2). https://doi.org/10.5206/cjsotl-rcacea.2017.2.8

Barkley, E. F., Major, C. H., \& Cross, K. P. (2014). Collaborative learning techniques: A handbook for college faculty (2nd ed.). CA, USA: Jossey-Bass.

Bhabha, H. (1994). The location of culture. London: Routledge.

Bovill, C. \& Felten, P. (2016). Cultivating student-staff partnerships through research and practice. International Journal for Academic Development, 21(1), 1-3, https://doi.org/10.1080/1360144X.2016.1124965

Bovill, C., Cook-Sather, A., Felten, P., Millard, L., \& Moore-Cherry, N. (2016). Addressing potential challenges in co-creating learning and teaching: Overcoming resistance, navigating institutional norms and ensuring inclusivity in student-staff partnerships. Higher Education, 71(2), 195-208. https://doi.org/10.1007/s10734-015-9896-4

Braun, V. \& Clarke, V. (2006). Using thematic analysis in psychology. Qualitative Research in Psychology, 3(2), 77-101. https://doi.org/10.1191/1478088706qp063oa

Cliffe, A., Cook-Sather, A., Healey, M., Healey, R., Marquis, E., Matthews, K. E., MercerMapstone, L., Ntem, A., Puri, V., \& Woolmer, C. (2017). Launching a journal about and through students as partners. International Journal for Students as Partners, 1(1). https://doi.org/10.15173/ijsap.v1i1.3194

Cook-Sather, Bovill, C., Felten, P. (2014). Engaging students as partners in learning and

McCollum, B. Morsch, L., Pinder, C., Ripley, I., Skagen, D., \& Wentzel, M. (2019). Multi-Dimensional 
teaching. San Francisco, CA: Jossey-Bass.

Festinger, L. (1954). A theory of social comparison processes. Human Relations, 7, 117-140. https://doi.org/10.1177/001872675400700202

Gutiérrez, K. (2008). Developing a sociocultural literacy in the third space. Reading Research Quarterly, 43(2), 148-164. https://doi.org/10.1598/RRQ.43.2.3

Healey, M., Flint, A., \& Harrington, K. (2014). Engagement through partnership: Students as partners in learning and teaching in higher education. Heslington, UK: The Higher Education Academy. Retrieved from https://www.heacademy.ac.uk/sites/default/files/resources/engagement through partn ership.pdf

Healey, M., Flint, A., \& Harrington, K. (2016). Students as partners: Reflections on a conceptual model. Teaching \& Learning Inquiry, 4(2). https://doi.org/10.20343/teachlearninqu.4.2.3

International Union of Pure and Applied Chemistry (IPUAC). (n.d.). Who we are: Strategic plan. Retrieved from https://iupac.org/who-we-are/strategic-plan/

McCollum, B., Fleming, C., Plotnikoff, K., \& Skagen, D. (2017). Relationships in the flipped classroom. The Canadian Journal for the Scholarship of Teaching and Learning, 8(3). https://doi.org/10.5206/cjsotl-rcacea.2017.3.8

McCollum, B., Morsch, L., Skagen, D., \& Shokoples, B. (in press). Overcoming barriers for implementing international online collaborative assignments in chemistry. The Canadian Journal for the Scholarship of Teaching and Learning.

McCollum, B., \& Morsch, L. (2019). Reading and relationships in organic chemistry. Manuscript submitted for publication.

Murphy, B., Nixon, S., Brooman, S., \& Fearon, D. (2017). "I am wary of giving too much power to students:" Addressing the "but" in the principle of staff-student partnership. International Journal for Students as Partners, 1(1). https://doi.org/10.15173/ijsap.v1i1.3055

Paterson, K. (2011). The darkside of collaboration: A pilot study. University of Alberta Education and Research Archive. https://doi.org/10.7939/R3J67934J

Potter, J. \& McDougall, J. (2017). Digital media, culture and education: Theorising Third Space literacies. Basingstoke, UK: Palgrave MacMillan.

Skagen, D., McCollum, B., Morsch, L. \& Shokoples, B. (2018). Developing communication confidence and professional identity in chemistry through international online collaborative learning. Chemistry Education Research and Practice, 19(2), 567-582. https://doi.org/10.1039/C7RP00220C

Skagen, D., McCollum, B., Morsch, L. \& Wentzel, M. (2019). “Chemistry is talked about the same way everywhere": Global learning through international collaborative learning partnerships. Manuscript in preparation.

Soja, E. W. (1996). Thirdspace journeys to Los Angeles and other real-and-imagined places. Malden, MA: Blackwell Publishers.

Sundberg, K., Josephson, A., Reeves, S., \& Nordquist, J. (2017). Power and resistance: Leading change in medical education. Studies in Higher Education, 42(3), 445-462. http://dx.doi.org/10.1080/03075079.2015.1052735

Wegner, D. (2011). Transitional writing and "Third Space" learning: Professional writing 
students and the work experience. Canadian Journal for Studies in Discourse and

Writing/Rédactologie, 23(1). https://doi.org/10.31468/cjsdwr.10 